\title{
Obtaining and characterization of bacterial cellulose synthesized by Komagataeibacter hansenii from alternative sources of nitrogen and carbon
}

\author{
Biassander Camila Tureck ${ }^{1}$, Haira Gabriela Hackbarth ${ }^{2}$, \\ Eduarda Zeni Neves ${ }^{1}$, Michele Cristina Formolo Garcia ${ }^{2}$, Giannini Pasiznick Apati ${ }^{2}$, \\ Derce de Oliveira Souza Recouvreux ${ }^{3}$, \\ Ana Paula Testa Pezzin ${ }^{1,2}$, Andrea Lima dos Santos Schneider ${ }^{2}$
}

\footnotetext{
'University of Joinville Region (UNIVILLE), Master's Program in Engineering of Processes, Paulo Malschitzki Street, n.10, block A, CP 246, CEP: 89201-972, Joinville Santa Catarina, Brazil

${ }^{2}$ University of Joinville Region (UNIVILLE), Department of Chemical Engineering, Paulo Malschitzki Street, n.10, block A, CP 246 - CEP: 89201-972. Joinville Santa Catarina, Brazil

Federal University of Santa Catarina (UFSC), Master's Program in Engineering and Mechanical Sciences, Dona Francisca Street, n.8300, block U, CP 246, 89219-600., Joinville Santa Catarina, Brazil

E-mail: anapezzin@yahoo.com.br
}

\begin{abstract}
This work aimed to obtain and characterize bacterial cellulose (BC) membranes obtained by cultivating Komagataeibacter hansenii ATCC 23769 using mannitol, glucose, fructose, lactose, glycerol, inulin, and sucrose as carbon sources, and corn steep liquor and Prodex Lac® as alternative sources of nitrogen. The formation of the $\mathrm{BC}$ 's gelatinous membrane was monitored for 12 days under static conditions and a temperature of $30^{\circ} \mathrm{C}$. After purification, the membranes were dried and characterized by thermogravimetric analysis (TGA), Fourier-transform infrared spectroscopy (FTIR), and scanning electron microscopy (SEM). The highest BC concentrations were found in the culture medium containing Prodex Lac ${ }^{\circledR}$ as the source of nitrogen. Among sugars, fructose and mannitol presented the best results. TGA analyzes indicate that all membranes have similar thermal behavior. The FTIR results show that the chemically synthesized membranes are equivalent to the structures cited in the literature. The micrographs obtained by SEM showed that the medium might influence BC's morphology, but in general, all presented nanofibers, an essential feature in the membrane. Thus, the $\mathrm{BC}$ membranes synthesized in this study proved that the $\mathrm{BC}$ production using low-cost alternative means is feasible. The material obtained meets the expected thermal, physical, and chemical properties.
\end{abstract}

Keywords: Bacterial cellulose, corn steep liquor, Prodex Lac®, nitrogen sources, carbon sources.

\section{INTRODUCTION}

Cellulose is the most abundant biopolymer on earth. A new cellulose material, bacterial cellulose (BC), has gained more attention in recent years. Bacterial cellulose is made up of $\beta$-D-glucopyranose monomers linked by $\beta(1-4)$ glycosides linkages. Different from cellulose from plants, BC has a three-dimension structure of an ultrafine nanofiber network. So, BC retains unique properties related to hydroxyl groups' ability to form supramolecular interactions of the type intra- and intermolecular [1]. Compared with cellulose from plants, BC is considered free of impurities, like lignin and hemicellulose molecules, challenging to remove. Consequently, cellulose has some distinguishing features, like high purity, high porosity, biocompatibility, high mechanical strength and stillness, biodegradability, and renewability, which makes this material attractive for industrial applications [2, 3].

In recent years, $\mathrm{BC}$ has been a focus for the development of health foods (coconut gel) [4], high-end electrical conductor [5], biomedical wound care products [6], cosmetic facial masks [7], sustainable clothing [8], effluent treatment [9] and other industrial applications, such as biodegradable materials for active packag- ing in food [10].

Several microorganisms can synthesize bacterial cellulose (BC) and, among them, the bacterium Komagataeibacter hansenii has been widely cited. The production of bacterial cellulose can be done by means of static cultures, which are the traditional ones, or in dynamic cultivations, that accelerate the production [11, 12]. Microorganisms are conventionally grown in media containing carbon sources, nitrogen sources and basic

nutrients to form of a hydrogel membrane of $\mathrm{BC}$. One of the common and traditional means used for the optimum production of cellulose from bacteria is Hestrin and Schramm's medium. However, low yield and 
prolonged fermentation conditions limit their production on a larger scale and enhance their properties. In recent years, studies have focused on various cellulose-producing bacterial strains, inexpensive nutrient sources, and supplementary materials to produce inexpensive BC. In this context, research has been carried out in search of media with high glucose content, such as fruit juices [13], maple syrup [14], various agricultural and industrial residues, such as molasses [15], sisal juice [16], carrot juice [17], hot water extracted wood sugars [18] to enhance cellulose production [19]. Although some authors have been successful in increasing CB production, depending on the nutritional source, they require considerable cultivation time, limiting production on an industrial scale, and some studies have not verified whether other substrates in the culture medium compromised the properties of the obtained polymer.

This work's objective was to evaluate the effect of different culture media, varying carbon, and nitrogen sources, aiming to optimize BC production. The utilization of corn steep liquor, a residue of maize maceration as a source of nitrogen, and a wild yeast extract are known commercially as Prodex Lac $®$, both of which have economic advantages, were evaluated. The membranes were characterized for their microstructure, chemical, and thermal analysis since the medium conditions can influence the properties and then direct future studies and applications.

\section{MATERIALS AND METHODS}

\subsection{Microorganism}

The microorganism used to evaluate the BC production was the bacterium Komagataeibacter hansenii (ATCC 23769) obtained from the "Tropical Culture Collection (CCT)" (Andre Tosello Foundation), Campinas/SP. The microorganisms were stored at $-80^{\circ} \mathrm{C}$ in a culture medium composed of mannitol, yeast extract, and peptone.

\subsection{Synthesis and purification of bacterial cellulose}

The inoculum was grown in a $1000 \mathrm{~mL}$ Erlenmeyer flask containing $400 \mathrm{~mL}$ of culture medium having the following composition: $20 \mathrm{~g} \mathrm{~L}^{-1}$ mannitol, $5 \mathrm{~g} \mathrm{~L}^{-1}$ yeast extract and $5 \mathrm{~g} \mathrm{~L}^{-1}$ peptone. To the sterilized culture medium was added, the microorganism $K$. hansenii. The culture time for activation was $48 \mathrm{~h}$ in a static condition at $30{ }^{\circ} \mathrm{C}$.

After cultivation, the cells were transferred at a $20 \%$ inoculum ratio to $125 \mathrm{~mL}$ Erlenmeyer flasks containing $20 \mathrm{~g} \mathrm{~L}^{-1}$ of the sugar to be investigated, $5 \mathrm{~g} \mathrm{~L}^{-1}$ of Prodex Lac® (P) (yeast autolysate, nitrogen source) or $5 \mathrm{~g} \mathrm{~L}^{-1}$ of Corn Steep Liquor (CSL) (nitrogen source) according to Table 1 . The culture was maintained at $30{ }^{\circ} \mathrm{C}$, with sampling done every two days for 12 days. [20].

Prodex Lac ${ }^{\circledR}$ is a wild yeast extract used as a source of low-cost vitamins to replace purified yeast extract

Corn steep liquor, a by-product of the corn wet-milling industry, consists of $50 \%$ water and is rich in vitamins, amino acids, minerals, and other growth stimulants. It is a viscous concentrated brown liquid with a $\mathrm{pH}$ of 3.7 to 4.1 [21]. Corn steep liquor can be used as the best alternative for yeast extract, as a nitrogen source in biochemical industries [22].

The hydrogel membrane formed culture medium's surface was collected, washed with distilled water and immersed in a $0.1 \mathrm{M} \mathrm{NaOH}$ solution at $80{ }^{\circ} \mathrm{C}$ for one h to eliminate cell debris and contaminants from the culture medium. Then the membrane was washed with distilled water repeatedly until neutral. The membranes obtained were dried under vacuum at $30^{\circ} \mathrm{C}$ for $48 \mathrm{~h}$ for the characterizations. 
Table 1: Culture media tested with their different compositions in relation to alternative sources of carbon and nitrogen.

\begin{tabular}{|c|c|c|}
\hline NITROGEN SOURCE $\left(5 \mathrm{~g} \mathrm{~L}^{-1}\right)$ & CARBON SOURCE $\left(20 \mathrm{~g} \mathrm{~L}^{-1}\right)$ & CULTURE MEDIA \\
\hline Yeast extract + Peptone & Mannitol & Control \\
\hline \multirow[t]{7}{*}{ Corn Steep Liquor (CSL) } & Fructose & CSL-Fru \\
\hline & Glucose & CSL-Glu \\
\hline & Glycerol & CSL-Gly \\
\hline & Inulin & CSL-Inu \\
\hline & Lactose & CSL-Lac \\
\hline & Mannitol & CSL-Man \\
\hline & Sucrose & CSL-Suc \\
\hline \multirow[t]{7}{*}{ Prodex Lac $®(\mathrm{P})$} & Fructose & P-Fru \\
\hline & Glucose & P-Glu \\
\hline & Glycerol & P-Gly \\
\hline & Inulin & P-Inu \\
\hline & Lactose & P-Lac \\
\hline & Mannitol & P-Man \\
\hline & Sucrose & P-Suc \\
\hline
\end{tabular}

\subsection{Characterization}

\subsubsection{Thermogravimetric analysis - TGA}

The TGA analyzes were performed to determine the thermal degradation, mass loss, thermal stability, degradation temperature $\left(\mathrm{T}_{\text {onset }}\right)$ and maximum degradation temperature $\left(\mathrm{T}_{\max }\right)$ of membranes. $\mathrm{TG}$ curves were obtained in an equipment TGA-Q50/TA Instruments. The samples were heated at 25 to $600{ }^{\circ} \mathrm{C}$ at $10{ }^{\circ} \mathrm{C} \mathrm{min}{ }^{-1}$ under a nitrogen atmosphere. The experimental parameters' adjustments were made in TA Universal Analysis software and graphically represented for better interpretation.

\subsubsection{Fourier-transform infrared spectroscopy - FTIR}

Characterization of functional groups of the membranes was performed by Fourier-transform infrared spectroscopy (FTIR) on Perkin Elmer Spectrum One equipment. Sixteen scans per sample were performed in the range of 4,000 to $650 \mathrm{~cm}^{-1}$, with a resolution of $4 \mathrm{~cm}^{-1}$ using the attenuated total reflectance (ATR) accessory.

\subsubsection{Scanning electron microscopy - SEM}

Samples of BC membranes were fixed in metal support and covered with a thin layer of gold using a BAL- TEC SCD 050 sample metallizer and observed by a scanning electron microscope (SEM) Zeiss DSM 940A, under a voltage of $10 \mathrm{kV}$, and magnification of $10,000 \mathrm{X}$. The software imageJ (public domain) was used to evaluate the images and measure the nanofibers' diameter.

\section{RESULTS AND DISCUSSION}

\subsection{Effect of nitrogen and carbon sources on membrane formation}

$\mathrm{BC}$ production is traditionally conducted from commercial culture media containing glucose as a source of carbon and other high-cost nutrients for the process. The use of carbon and nitrogen sources from agro-indus- trial wastes is an alternative to lower costs in obtaining biotech products. The use of these wastes contributes to lower production costs and fewer environmental impacts caused by improper disposal of these materials. Several successful by-products such as corn steep liquor [23], sugar cane molasses [24], cheese whey [11], fruit juices [13] has been used for this purpose. As shown in Figure 1, there was BC's formation for both nitrogen sources tested, regardless of the carbon source. However, Prodex Lac® provided higher yields of BC. 


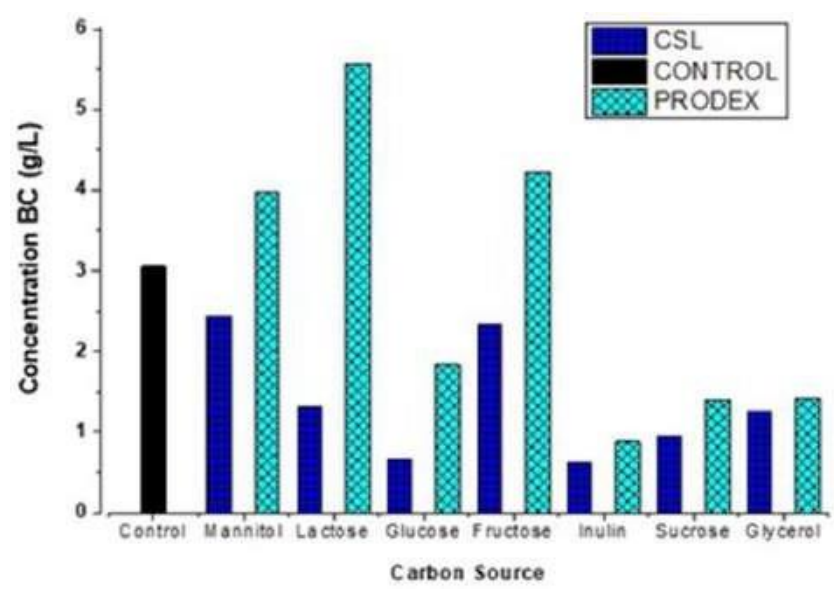

Figure 1: Formation of BC by K. hansenii varying carbon and nitrogen sources.

The performance of Prodex Lac ${ }^{\circledR}$ can be justified because it is a wild yeast extract, while the conventional medium for BC cultivation uses nitrogen as a source of yeast and peptone extract. Prodex Lac $®$ is considered a source of low-cost vitamins (especially the B-complex) used in industrial biotechnology to replace the purified yeast extract. Prodex Lac $\square$ has also been shown to be beneficial in the production of $\beta$ - galactosidase by yeasts [25], and in the production of glucosyltransferase by Erwinia sp to obtain maximum enzymatic activity and reduced costs in the fermentation process [26].

Regardless of the nitrogen source, it is observed that all carbon sources result in the formation of $\mathrm{BC}$, and the best yields (5.50, 4.20 and $\left.4.00 \mathrm{~g} \mathrm{~L}^{-1}\right)$ were found in lactose, fructose, and mannitol, respectively.

The results obtained for the synthesis of $\mathrm{BC}$ containing mannitol and glucose as carbon sources were 4.00 and $1.75 \mathrm{~g} \mathrm{~L}^{-1}$ (having Prodex Lac ${ }^{\circ}$ as nitrogen source) and 2.40 and $0.60 \mathrm{~g} \mathrm{~L}^{-1}$ (taking corn steep liquor as nitrogen source). Hutchens et al. compared mannitol and glucose, having better results with mannitol, about 50\% by mass [27]. According to the authors, mannitol is a sugar alcohol, which provides electrons for the metabolism of bacteria and stimulates a higher yield of cellulose than glucose.

In the assay containing fructose and glucose as carbon source, BC's formation was $4.20 \mathrm{~g} \mathrm{~L}^{-1}$ and $1.75 \mathrm{~g} \mathrm{~L}^{-1}$, respectively, having Prodex Lac ${ }^{\circledR}$ as the nitrogen source. According to SANTOS et al. [28], glucose and sucrose provided low $\mathrm{BC}$ production in a short period, while glycerol, mannitol, and fructose allowed consistent production throughout the growing time and in larger amounts when compared to glucose and sucrose. According to the carbon source, different production rates were also described by MIKKELSEN et al. [29]. The results revealed that cellulose production was stimulated by all carbon sources tested for $96 \mathrm{~h}$ of production, except for galactose. In $48 \mathrm{~h}$ of culture, mannitol yielded the highest yields in BC $\left(2.04 \mathrm{~g} \mathrm{~L}^{-1}\right)$. It produced relatively high cellulose concentrations $\left(1.89\right.$ and $\left.1.79 \mathrm{~g} \mathrm{~L}^{-1}\right)$, respectively.

The concentrations resulting from the lactose use were $5.57 \mathrm{~g} \mathrm{~L}^{-1}$ in the medium containing Prodex Lac $®$ and only $1.31 \mathrm{~g} \mathrm{~L}^{-1}$ for the medium containing corn steep liquor. TSOUKO et al. [30] obtained a low concentration of $\mathrm{BC}$ when lactose was used as a carbon source, attributing this result to the fact that the genus Gluconacetobacter does not have the gene coding for $\beta$-galactosidase, the enzyme responsible for the hydrolysis of lactose. However, in this study, in conjunction with Prodex Lac ${ }^{\circledR}$, an opposite behavior was observed, resulting in a high BC concentration, indicating that the nitrogen source can influence the synthesis, providing a higher yield.

The low production performance when using glucose as a carbon source, $1.83 \mathrm{~g} \mathrm{~L}^{-1}$, and $0.67 \mathrm{~g} \mathrm{~L}^{-1}$, and as a source of nitrogen Prodex Lac ${ }^{\circledR}$ and corn steep liquor, respectively, was also reported by SANTOS et al., [28] which obtained only $1.2 \mathrm{~g} \mathrm{~L}^{-1}$ with this same carbon source. These authors justify correlating BC production with the carbon source rate, showing that glucose is consumed faster than the other carbon sources. Besides, glucose can be easily transported through the cell membrane and incorporated into the cellulose biosynthetic pathway. However, it has been reported that most glucose is converted into gluconic acid byproducts, which decreases the $\mathrm{pH}$ of the crop, causing lower $\mathrm{BC}$ production [31].

The use of glycerol did not sho results for BC formation, being $1.42 \mathrm{~g} \mathrm{~L}^{-1}$ when associated with Prodex Lac ${ }^{\circledR}$ and $1.26 \mathrm{~g} \mathrm{~L}^{-1}$ along with corn steep liquor, diverging from another study that obtained $3.50 \mathrm{~g} \mathrm{~L}^{-1}$ [30]. These results indicate that the interaction between the nitrogen source and the carbon source influences the $\mathrm{BC}$ synthesis. The same occurred when sucrose was used, which resulted in low concentrations, $1.40 \mathrm{~g} \mathrm{~L}^{-1}$ in the medium containing Prodex Lac ${ }^{\circledR}$ and $0.94 \mathrm{~g} \mathrm{~L}^{-1}$ in medium with corn steep liquor, while TSOUKO et al. [30] reported yielding $4.90 \mathrm{~g} \mathrm{~L}^{-1}$.

Of all the carbon sources investigated, inulin showed the lowest yields, $0.88 \mathrm{~g} \mathrm{~L}^{-1}$ using Prodex Lac ${ }^{\circledR}$ and $0.66 \mathrm{~g} \mathrm{~L}^{-1}$ for corn steep liquor. This fact can be justified by the complexity of the bonds present in this polymer. TIBONI [32] suggests using fructooligosaccharides (FOS) as an alternative source of carbon since this can be obtained by hydrolyzed inulin with soft catalysts such as phosphoric acid and citric acid. In this way, the bacterium uses this sugar more efficiently, increasing its conversion in BC. 
All these results show that cellulose synthesis by bacteria is complex and is affected by many factors. A better yield in $\mathrm{BC}$ production may depend on the effective use of the carbon and nitrogen sources. Considering the diversity of enzymes and metabolic pathways present in BC-producing bacteria, several carbon sources can be used to develop and produce BC, yielding different yields [31].

\subsection{Thermogravimetric analysis - TGA}

The thermogravimetric curves (TG and DTG) obtained from TGA for BC membranes synthesized from dif- ferent carbon sources, containing Corn Steep Liquor and Prodex Lac $\AA$ as a nitrogen source, are presented in Figure 2a and $2 \mathrm{~b}$, respectively. The extrapolated onset temperature $\left(\mathrm{T}_{\text {onset }}\right)$, which denotes the temperature at which the mass loss begins, was taken as the temperature at which the mass loss started, as is shown in Figure $2 \mathrm{a}$ and $2 \mathrm{c}$. The temperature of the maximum mass loss rate $\left(\mathrm{T}_{\max }\right.$ ) was calculated from the first derivative of the TG curve (DTG), and it indicates the point of the most significant rate of change on the mass loss curve (Figure $2 \mathrm{~b}$ and $2 \mathrm{~d}$ ). The extrapolated onset temperature $\left(\mathrm{T}_{\text {onset }}\right)$, the temperature of maximum mass loss rate $\left(\mathrm{T}_{\max }\right)$, percentage of mass loss, and residual mass percentage at $600{ }^{\circ} \mathrm{C}$ are shown in Table 2.

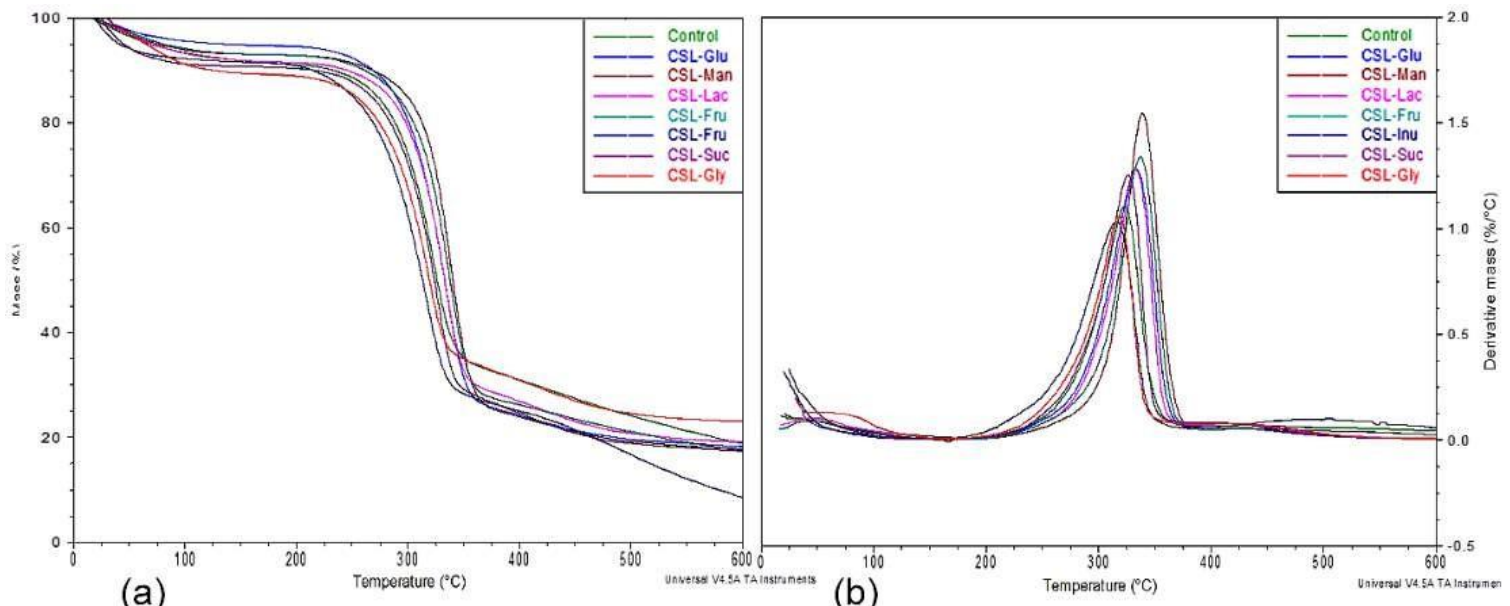

(a)

(b)

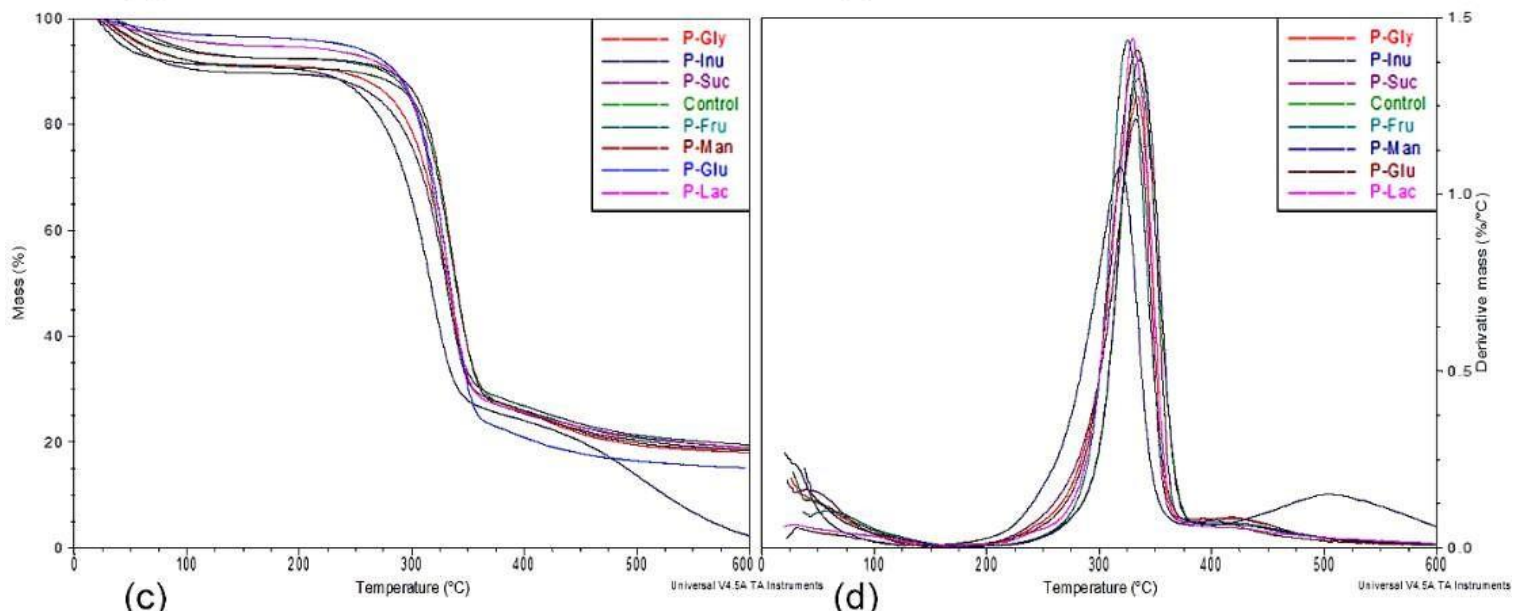

Figure 2: BC curves synthesized from different carbon sources: TG (a) and DTG curves (b) for Corn Steep Liquor (CSL) as nitrogen source; TG (c) and DTG curves (d) for Prodex Lac® as nitrogen source. 
The degradation profile of the control BC membranes shows three mass-loss events. The first thermal event that presented mass loss between $9.1 \%$ is associated with water loss between 30 and $150{ }^{\circ} \mathrm{C}$ [33]. The second event was more pronounced and occurred in $\mathrm{T}_{\text {onset } 2}=309^{\circ} \mathrm{C}$ with $64.9 \%$ mass loss and $\mathrm{T}_{\max 2}=335^{\circ} \mathrm{C}$, according to Gea et al. [34] is attributed to cellulose degradation, including depolymerization and decomposi- tion of glucose units. The third event represents the degradation of carbonaceous residues that extends from 400 to $1000{ }^{\circ} \mathrm{C}$ with a percentage of residual at $600{ }^{\circ} \mathrm{C}$ determined was $19 \%$ [34].

For the other samples, the mass loss percentage of the first stage varied between 3.4 and $10.5{ }^{\circ} \mathrm{C}$, evidencing BC's high hygroscopicity. The maximum decomposition temperature is a criterion of thermal stability. The determined $\mathrm{T}_{\max 2}$ varied between 316 and $339{ }^{\circ} \mathrm{C}$, so that CSL-Man $\left(339{ }^{\circ} \mathrm{C}\right)$, CSL-Frut $\left(337{ }^{\circ} \mathrm{C}\right)$ and Prodex Lac $₫-M a n\left(336{ }^{\circ} \mathrm{C}\right)$ presented slightly higher thermal stability than the control sample. It is also veri- fied that the means that provided the higher concentration of $\mathrm{BC}$ were the same ones that also presented better results in the thermal analyzes. Similarly, the means that provided lower BC membrane formation were, pre- cisely, the ones that showed lower values for $\mathrm{T}_{\max }$, such as P-Inu $\left(318{ }^{\circ} \mathrm{C}\right)$ and $\mathrm{CSL}-\mathrm{Inu}\left(316^{\circ} \mathrm{C}\right)$, showing lower thermal stability. The $\mathrm{T}_{\max 2}$ data obtained in this work were much lower than the $\mathrm{T}_{\max 2}$ values of $\mathrm{BC}$ membranes produced by Gluconacetobacter xylinus using low-cost non-conventional carbon sources investi- gated by Vazquez et al. [35], which obtained values between 353 and $379^{\circ} \mathrm{C}$. The lower thermal stability of this work's BC membranes of can be explained by the different strains used by Vazquez et al. [35]. The third event represents the degradation of carbonaceous residues that extends from 400 to $600{ }^{\circ} \mathrm{C}$, with a percentage of residues found ranging from 2.3 to 23.1\%. It was observed that CLS-Inu and P-Inu membranes were the ones with the lowest residue content.

Table 2: $\mathrm{T}_{\text {onset }}, \mathrm{T}_{\max }$, percentage of mass loss and percentage of residual mass at $600{ }^{\circ} \mathrm{C}$ determined from the TG and DTG curves of the BC samples synthesized from different sources of carbon and having Corn Steep Liquor and Prodex Lac ${ }^{\circledR}$ as sources of nitrogen.

\begin{tabular}{|c|c|c|c|c|c|c|}
\hline $\begin{array}{c}\text { NITROGEN SOURCE: } \\
\text { CORN STEEP LIQUOR } \\
\text { (CSL) }\end{array}$ & $\begin{array}{c}\text { MASS LOSS } 1 \\
(\%)\end{array}$ & $\mathrm{T}_{\text {onset2 } 2}\left({ }^{\circ} \mathrm{C}\right)$ & $\begin{array}{c}\text { MASS LOSS } 2 \\
(\%)\end{array}$ & $\mathbf{T}_{\max 2}\left({ }^{\circ} \mathrm{C}\right)$ & $\begin{array}{c}\text { MASS LOSS } 3 \\
(\%)\end{array}$ & $\begin{array}{c}\text { RESIDUAL AT } 600^{\circ} \mathrm{C} \\
(\%)\end{array}$ \\
\hline Control & 9.1 & 309 & 64.9 & 335 & 6.9 & 19.0 \\
\hline CSL-Gly & 10.5 & 281 & 58.7 & 319 & 7.9 & 23.1 \\
\hline CSL-Man & 6.6 & 313 & 69.3 & 339 & 6.0 & 17.8 \\
\hline CSL-Glu & 4.8 & 299 & 70.8 & 333 & 5.9 & 18.3 \\
\hline CSL-Fru & 6.7 & 306 & 67.0 & 337 & 8.7 & 17.5 \\
\hline CSL-Inu & 8.2 & 273 & 66.7 & 316 & 16.5 & 8.6 \\
\hline CSL-Suc & 9.0 & 292 & 66.2 & 326 & 7.2 & 17.5 \\
\hline CSL-Lac & 7.9 & 301 & 65.0 & 333 & 7.8 & 19.2 \\
\hline $\begin{array}{l}\text { NITROGEN SOURCE: } \\
\text { PRODEX LAC® (P) }\end{array}$ & $\begin{array}{c}\text { MASS LOSS } 1 \\
(\%)\end{array}$ & $\mathrm{T}_{\text {onset2 } 2}\left({ }^{\circ} \mathrm{C}\right)$ & $\begin{array}{c}\text { MASS LOSS } 2 \\
(\%) \\
\end{array}$ & $\mathbf{T}_{\max 2}\left({ }^{\circ} \mathrm{C}\right)$ & $\begin{array}{c}\text { MASS LOSS } 3 \\
(\%)\end{array}$ & $\begin{array}{c}\text { RESIDUAL AT } 600^{\circ} \mathrm{C} \\
(\%)\end{array}$ \\
\hline Control & 9.1 & 309 & 64.9 & 335 & 6.9 & 19.0 \\
\hline P-Gly & 3.4 & 302 & 75.7 & 333 & 5.7 & 15.2 \\
\hline P-Man & 7.3 & 309 & 67.3 & 336 & 6.7 & 18.6 \\
\hline P-Glu & 8.8 & 301 & 65.5 & 334 & 7.7 & 18.0 \\
\hline P-Fru & 7.1 & 302 & 66.0 & 325 & 7.2 & 19.5 \\
\hline P-Inu & 8.8 & 280 & 67.1 & 318 & 21.7 & 2.3 \\
\hline P-Suc & 9.9 & 298 & 63.9 & 332 & 7.6 & 18.3 \\
\hline P-Lac & 5.0 & 301 & 69.4 & 330 & 6.5 & 19.1 \\
\hline
\end{tabular}

$\mathrm{T}_{\text {onset }}=$ extrapolated onset temperature; $\mathrm{T}_{\max }=$ temperature of maximum mass loss rate.

\subsection{Fourier-transform infrared spectroscopy - FTIR}

The FTIR spectra of the membranes obtained from the different culture media were carried out to prove the polymer's synthesis is shown in Figure 3. 
The main bands of BC control are: a broad band at $3341 \mathrm{~cm}^{-1}$ attributed to the $\mathrm{U}(\mathrm{OH})$ of type I cellulose and to intramolecular bonds $(3-\mathrm{OH} \ldots \mathrm{O}-5)$; a $2897 \mathrm{~cm}^{-1}$ band attributed to $\mathrm{U}(\mathrm{CH})$ and $\mathrm{Ua}\left(\mathrm{CH}_{2}\right) ;$ a $1641 \mathrm{~cm}^{-1}$ band characteristic of $\delta(\mathrm{OH})$; a band at $1400 \mathrm{~cm}^{-1}$ relative to $\delta\left(\mathrm{CH}_{2}\right)$; a band at $1369 \mathrm{~cm}^{-1}$ related to $\delta(\mathrm{CH})$; a $1335 \mathrm{~cm}^{-1}$ band assigned $\delta(\mathrm{OH})$; an intense band at $1159 \mathrm{~cm}^{-1}$ referring to the glycosidic linking ring $(\mathrm{C}-\mathrm{O}-\mathrm{C})$ derived from the cellulose backbone; a band at $1110 \mathrm{~cm}^{-1}$ referring to $\mathrm{U}(\mathrm{C} 2 \ldots \mathrm{O} 2)$; a $1052 \mathrm{~cm}^{-1}$ band corre- sponding to $\mathrm{U}(\mathrm{CO}) /(\mathrm{CC})$ and another band at $1029 \mathrm{~cm}^{-1}$ attributed to $\mathrm{Us}(\mathrm{CO}) /(\mathrm{CC})$ and another $1003 \mathrm{~cm}^{-1}$ intense band related to $\mathrm{U}(\mathrm{C} 3 \ldots \mathrm{O} 3)$, referring to the main bond-forming the crosslinking. There are also two tiny bands related to cellulose $\mathrm{I}_{\alpha}\left(750 \mathrm{~cm}^{-1}\right)$ and $\mathrm{I}_{\beta}\left(710 \mathrm{~cm}^{-1}\right)$. These bands are also present in the other samples, proving BC's production in all sources tested [2, $34-36]$. The bands attributed to BC are also presented in Table 3.

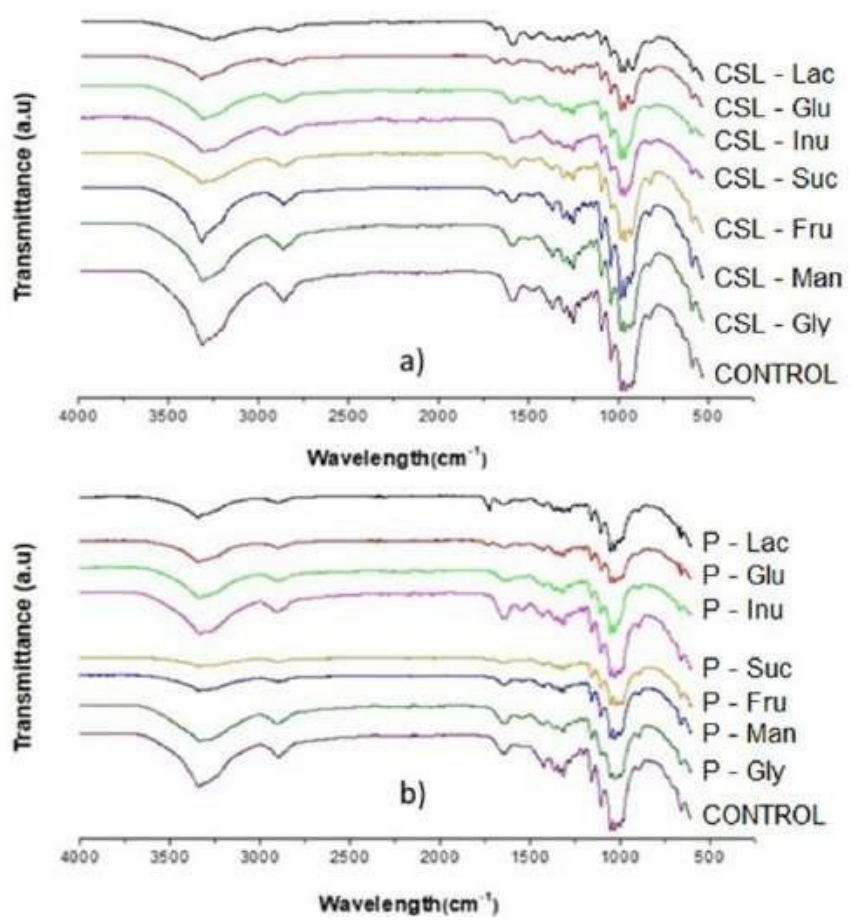

Figure 3: FTIR spectra of membranes synthesized from different carbon sources, having as nitrogen source: a) corn steep liquor (CSL), b) Prodex Lac®. 
Table 3: Assignment of bacterial cellulose FTIR absorption bands as they were observed in the membranes synthesized from different carbon sources, having as nitrogen source corn steep liquor (CSL), and Prodex Lac ${ }^{\circledR}(\mathrm{P})$.

\begin{tabular}{|c|c|c|c|c|c|c|c|c|c|}
\hline ASSIGNMENT & $\begin{array}{c}\text { WAVELENGT } \\
\mathbf{H} \\
\left(\mathrm{cm}^{-1}\right)^{\star} \\
\end{array}$ & CONTROL & CSL-GLY & CSL-MAN & CSL-FRU & CSL-SUC & CSL-INU & CSL-GLU & CSL-LAC \\
\hline $\begin{array}{l}v(\mathrm{O}-\mathrm{H}) \\
\text { Celullose I } \\
(3-\mathrm{OH} . . . \mathrm{O}-5)\end{array}$ & 3340 & 3341 & 3340 & 3347 & 3347 & 3341 & 3341 & 3341 & 3327 \\
\hline $\begin{array}{l}\text { v(CH); va } \\
(\mathrm{CH} 2)\end{array}$ & 2900 & 2897 & 2896 & 2896 & 2903 & 2903 & 2896 & 2896 & 2909 \\
\hline$\delta(\mathbf{O H})$ & 1641 & 1642 & 1645 & 1645 & 1645 & 1640 & 1645 & 1645 & 1645 \\
\hline$\delta(\mathrm{CH} 2)$ & 1428 & 1426 & 1426 & 1428 & 1428 & 1427 & 1427 & 1427 & 1428 \\
\hline$\delta(\mathbf{C H})$ & 1369 & 1364 & 1364 & 1367 & 1369 & 1364 & 1367 & 1367 & 1369 \\
\hline$\delta(\mathbf{O H})$ & 1335 & 1335 & 1336 & 1337 & 1339 & 1337 & 1337 & 1337 & 1337 \\
\hline va(C-O-C) & 1159 & 1160 & 1160 & 1160 & 1162 & 1160 & 1162 & 1162 & 1160 \\
\hline$v(\mathrm{C} 2 \ldots \mathrm{O} 2)$ & 1110 & 1107 & 1107 & 1107 & 1110 & 1110 & 1110 & 1110 & 1110 \\
\hline $\begin{array}{l}v(C-O) /(C- \\
\text { C) }\end{array}$ & 1052 & 1052 & 1052 & 1057 & 1057 & 1057 & 1057 & 1054 & 1055 \\
\hline $\operatorname{vs}(\mathrm{C}-\mathrm{O}) /(\mathrm{C}-\mathrm{C})$ & 1029 & 1030 & 1030 & 1030 & 1030 & 1030 & 1030 & 1030 & 1030 \\
\hline $\mathrm{v}(\mathrm{C} 3 \ldots \mathrm{O3})$ & 1003 & 1002 & 1002 & 1002 & 1000 & 1000 & 1001 & 1001 & 1001 \\
\hline Cellulose I $\alpha$ & 750 & 749 & 749 & 749 & 749 & 750 & 749 & 750 & 750 \\
\hline Celluose I $\beta$ & 710 & 709 & 710 & 710 & 709 & 710 & 710 & 710 & 710 \\
\hline ASSIGNMENT & $\begin{array}{c}\text { WAVELENGT } \\
\mathbf{H} \\
\left(\mathrm{cm}^{-1}\right)^{*}\end{array}$ & CONTROL & P-GLY & P-MAN & P-FRU & P-SUC & P-INU & P-GLU & P-LAC \\
\hline $\begin{array}{l}v(\mathrm{O}-\mathrm{H}) \\
\text { Celullose I } \\
(3-\mathrm{OH} . . . \mathrm{O}-5)\end{array}$ & 3340 & 3340 & 3333 & 3340 & 3340 & 3340 & 3340 & 3348 & 3348 \\
\hline $\begin{array}{l}\text { v(CH); va } \\
\text { (CH2) }\end{array}$ & 2900 & 2898 & 2898 & 2898 & 2898 & 2898 & 2898 & 2898 & 2898 \\
\hline$\delta(\mathrm{OH})$ & 1641 & 1648 & 1648 & 1647 & 1642 & 1648 & 1642 & 1642 & 1642 \\
\hline$\delta(\mathrm{CH} 2)$ & 1428 & 1429 & 1428 & 1430 & 1430 & 1428 & 1426 & 1430 & 1430 \\
\hline$\delta(\mathbf{C H})$ & 1369 & 1368 & 1368 & 1368 & 1368 & 1368 & 1368 & 1368 & 1368 \\
\hline$\delta(\mathrm{OH})$ & 1335 & 1336 & 1337 & 1337 & 1337 & 1337 & 1337 & 1337 & 1337 \\
\hline va(C-O-C) & 1159 & 1161 & 1161 & 1163 & 1161 & 1159 & 1161 & 1161 & 1164 \\
\hline $\mathrm{v}(\mathrm{C} 2 \ldots \mathrm{O} 2)$ & 1110 & 1110 & 1110 & 1110 & 1110 & 1110 & 1110 & 1110 & 1110 \\
\hline $\begin{array}{l}v(\mathrm{C}-\mathrm{O}) /(\mathrm{C}- \\
\mathrm{C})\end{array}$ & 1052 & 1053 & 1054 & 1056 & 1054 & 1054 & 1054 & 1054 & 1056 \\
\hline $\operatorname{vs}(\mathrm{C}-\mathrm{O}) /(\mathrm{C}-\mathrm{C})$ & 1029 & 1030 & 1030 & 1030 & 1030 & 1030 & 1030 & 1030 & 1030 \\
\hline$v(C 3 \ldots . .03)$ & 1003 & 1002 & 1000 & 1000 & 1004 & 1000 & 1000 & 1003 & 1000 \\
\hline Cellulose I $\alpha$ & 750 & 749 & 748 & 750 & - & 750 & 748 & 749 & 749 \\
\hline Cellulose I $\beta$ & 710 & 710 & 711 & 711 & 711 & 710 & 711 & 711 & 710 \\
\hline
\end{tabular}

$v=$ stretching; $\delta=$ angular bending; $\mathrm{s}=$ symmetric; $\mathrm{a}=$ asymmetric.

* Wavenumber obtained from the literature [2, 34 -36] 


\subsection{Scanning electron microscopy - SEM}

The micrographs of the surfaces of the BC membranes obtained from the different carbon sources are presented in Figure 4 and 5, using as a nitrogen source, corn steep liquor, and Prodex Lac®, respectively.
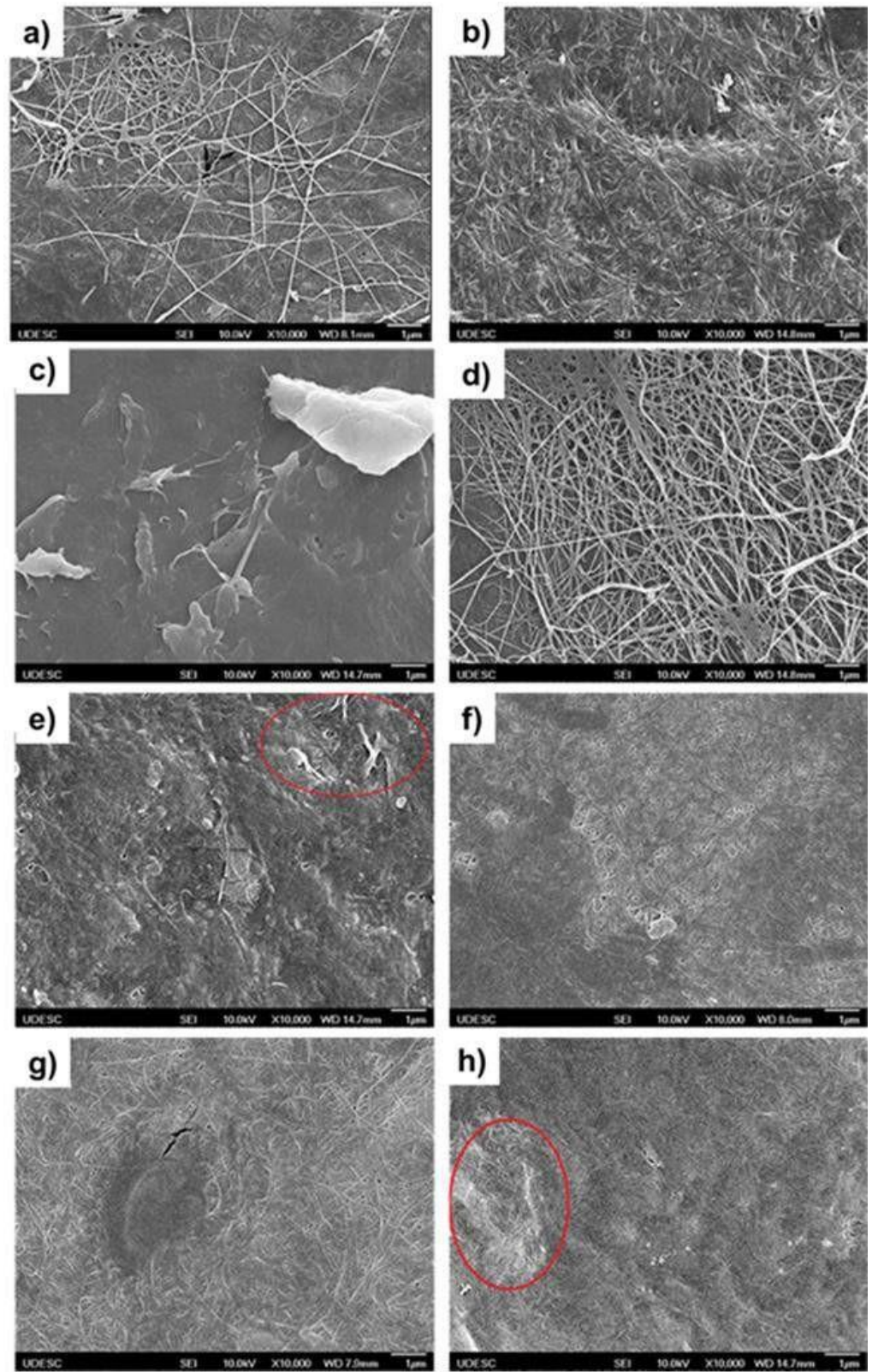

Figure 4: Micrographies of BC obtained from CSL and different sources of carbon: a) control; b) CSL-Gly; c) CSL-Man; d) CSL-Fru; e) CSL-Suc; f) CSL-Inu; g) CSL-Glu e h) CSL-Lac. 

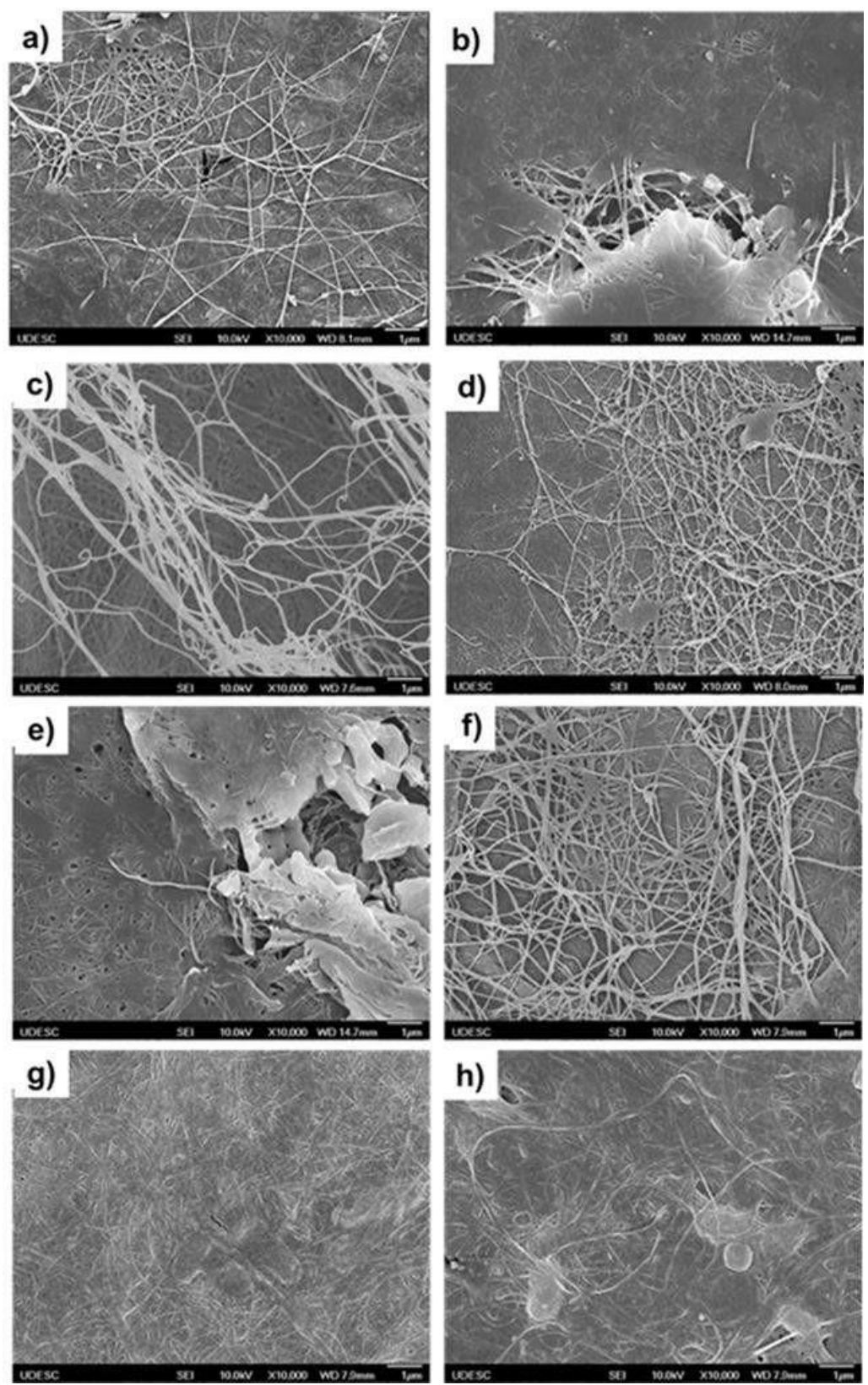

Figure 5: Micrographies of BC obtained from Prodex Lac ${ }^{\circledR}$ and different carbon sources: a) control; b) P-Gly; c) P-Man; d) P-Fru; e) P-Suc; f) P-Inu; g) P-Glu e h) P-Lac.

The membrane produced in yeast extract, peptone, and mannitol (control) medium (Figure 4a and 5a), as well as the other synthesized membranes, presented a network of randomly distributed nanofibers with high aspect ratio and diameter varying between 18 and $90 \mathrm{~nm}$, measured with the ImageJ software, strong morphological characteristics of $\mathrm{BC}[37,38]$. 
The membranes of BC produced in a medium using Corn Steep Liquor with fructose (CSL-Fru) (Figure 4d) and Prodex Lac ${ }^{\circledR}$ with fructose (P-Fru), inulin (P-Inu) and mannitol (P-Man) presented in (Figure 5c, 5d and 5f), respectively showed good dispersion of the nanofibers within the matrix, with no visible aggregates, like other micrographs typical of $\mathrm{BC}$ found in the literature $[31,35]$.

The membranes of BC produced in medium containing corn steep liquor with glycerol (CSL-Gly) (Figure 4b), fructose (CSL-Fru) (Figure 4d), inulin (CSL-Inu) (Figure 4f), glucose (CSL-Glu) (Figure 4g) and lactose (CSL-Lac) (Figure 4h) also showed good dispersion of the nanofibers in the matrix, but in a more dense form, which was also observed in samples cultured in Prodex Lac ${ }^{\circledR}$ medium with glucose (P-Glu) (Figure 5g) e lactose (P-lac) (Figure $5 \mathrm{~h}$ ). They also appeared smooth and dense.

The membranes of BC produced in medium containing corn steep liquor and sucrose (CSL-Suc) (Figure 4e) and corn steep liquor and lactose (CSL-Lac) (Figure 4h) were also dense. However, although nanofibers have been observed, they are heterogeneously arranged in the matrix, as highlighted in the figures (circle). The same observation can be observed for the membranes obtained in culture medium containing Prodex Lac ${ }^{\circledR}$ with glycerol (P-Gly) (Figure 5b) and Prodex Lac ${ }^{\circledR}$ with sucrose (P-Suc) (Figure 5e).

Finally, in the micrograph of the $\mathrm{BC}$ membrane produced in a medium containing corn steep liquor and mannitol (Figure 5f) it is impossible to observe the nanofibers in the matrix. This membrane was smooth, dense and with presence of whitish aggregates.

The formation of $\mathrm{BC}$ pellicle may be impacted by the overall medium composition, carbon source, and factors related to the operational conditions (e.g. $\mathrm{pH}$, temperature, agitation or not of the medium, size and shape of the container, etc.). MOHAMMADKAZEMI et al. [33] and KLEMM et al. [39] evaluated BC production in different carbon sources and culture media and found that the medium may result in different morphologies.

According to Vieira et al. [40] all the BC membranes tend to have a similar structure. However, the pore size and quantity are different due media components and cellulose fibers' interaction.

These differences may influence cellulose's final application, where more porous or compact structures are required to create a device or product [41]. The high aspect ratio of nanofibrils affects the membrane's mechanical properties such as tensile strength elasticity [37].

\section{CONCLUSIONS}

The results obtained show that it is possible to obtain $\mathrm{BC}$ from different culture media compositions, varying nitrogen and carbon sources, using the bacterium $K$. hansenii in static culture.

Among the nitrogen sources analyzed, Prodex Lac ${ }^{\circledR}$ was more efficient, resulting in higher yields of BC. The sources of carbon, fructose, mannitol, and lactose presented higher yields than the others. The results of TGA indicate that all the samples of $\mathrm{BC}$ have similar thermal behavior, and the most thermally stable were CSL-Man $\left(339^{\circ} \mathrm{C}\right)$, CSL-Fru $\left(337^{\circ} \mathrm{C}\right)$ and P-Man $\left(335^{\circ} \mathrm{C}\right)$. The FTIR results show that the different samples are chemically equivalent to the structures cited in the literature. The micrographs showed that the medium might influence BC's morphology, but in general, the microstructure consists of an interwoven network of randomly distributed cellulose nanofibers, an essential feature for several applications.

Following the structure presented, it is concluded that $\mathrm{BC}^{\prime} \mathrm{s}$ production using alternative means and low cost is feasible and that the material obtained presents the characteristic thermal, physical and chemical prop-erties of the cellulose.

\section{ACKNOWLEDGMENTS}

This study was financed in part by the Coordenação de Aperfeiçoamento de Pessoal de Nível Superior - Brasil (CAPES) - Finance Code 001 and Research Support Fund of the University of Region Joinville - UNIVILLE.

\section{BIBLIOGRAPHY}

[1] MACHADO, R.T.A., MENEGUIN, A.B., SÁBIO, R.M., et al., "Komagataeibacter rhaeticus grown in sugarcane molasses-supplemented culture medium as a strategy for enhancing bacterial cellulose production", Industrial Crops and Products, v. 122, pp. 637-646, Oct. 2018.

[2] CHEN, X.I., Degradation Studies on Plant Cellulose and Bacterial Cellulose by FT-IR and ESEM, Thesis of Ph.D, University of Birmingham, Birmingham, England, UK, 2014.

[3] AMORIM, J.D.P., SOUZA, K.C., DUARTE, C.R., et al., "Plant and bacterial nanocellulose: production, properties and applications in medicine, food, cosmetics, electronics and engineering. A review", Environmental Chemistry Letters, v. 18, n. 3, pp. 851-869, Mar. 2020. 
[4] IGUCHI, M., YAMANAKA, S., BUDHIONO, A., "Bacterial cellulose - a masterpiece of nature's arts", Journal of Materials Science, v. 5, n. 35, pp. 261-270, Jan. 2000.

[5] WAN, Y., LI, J., YANG, Z., et al., "Simultaneously depositing polyaniline onto bacterial cellulose nanofibers and graphene nanosheets toward electrically conductive nanocomposites", Current Applied Physics, v. 18, n. 8, pp. 933-940, Aug. 2018.

[6] PORTELA, R., LEAL, C.R., ALMEIDA, P.L., et al., "Bacterial cellulose: a versatile biopolymer for wound dressing applications”, Microbial Biotechnology, v. 12, n. 4, pp. 586-610, Jul. 2019.

[7] PERUGINI, P., BLEVE, M., REDONDI, R., et al., "In vivo evaluation of the effectiveness of biocellulose facial masks as active delivery systems to skin", Journal of Cosmetic Dermatology, v. 19, n. 3, pp. 725-735, Mar. 2020.

[8] COSTA, A.F.S., AMORIM, J.D.P., ALMEIDA, et al., "Dyeing of bacterial cellulose films using plant- based natural dyes", International Journal of Biological Macromolecules, v. 121, pp. 580-587, Jan. 2019.

[9] GALÁRRAGA, J.C.V., BARUD, H.S., SANTOS, F.K., et al., "MULTIPOINT IMMOBILIZATION AND STABILIZATION OF AMINED PEROXIDASES FROM SOYBEAN HULL AND CHAYOTE EMPLOYING BACTERIAL CELLULOSE AS SUPPORT", Cellulose Chemistry and Technology, v. 54, n. 3-4, pp. 275-283, 2020.

[10] YORDSHAHI, A.S., MORADI, M., TAJIK, H., et al., "Design and preparation of antimicrobial meat wrapping nanopaper with bacterial cellulose and postbiotics of lactic acid bacterium", International Journal of Food Microbiology, v. 321, pp. 1-10, May. 2020.

[11] ISLAM, M.U., ULLAH, M.W., KHAN, S., et al., "Strategies for cost-effective and enhanced production of bacterial celulose", International Journal of Biological Macromolecules, v. 102, pp. 1166-1173, Sep. 2017.

[12] ESA, F., TASIRIN, S.M., RAHMAN, N.A., "Overview of Bacterial Cellulose Production and Application", Agriculture and Agricultural Science Procedia, v. 2, pp. 113-119, Nov. 2014.

[13] KUROSUMI, A., SASAKI, C., YAMASHITA, Y., et al., "Utilization of various fruit juices as carbon source for production of bacterial cellulose by Acetobacter xylinum NBRC 13693", Carbohydrate Polymers, v. 76, n. 2, pp. 333-335. Mar. 2009.

[14] ZENG, X., PEQUENO, D.P, WAN, W., "Statistical optimization of culture conditions for bacterial cellulose production by Acetobacter xylinum BPR 2001 from maple syrup", Carbohydrate Polymers, v. 85, n. 3, pp. 506513, Jun. 2011.

[15] KHATTAK, W.A., KHAN, T., UL-ISLAM, M., et al., "Production, Characterization and Physicomechanical Properties of Bacterial Cellulose from Industrial Wastes", Journal of Polymers and the Environment, v. 23, n. 1, pp. 45-53, Jun. 2015.

[16] LIMA, H.L.S., NASCIMENTO, E.S., ANDRADE, F.K., et al., "Bacterial cellulose production by Komagataeibacter hansenii ATCC 23769 using sisal juice - An agroindustry waste", Brazilian Journal of Chemical Engineering, v. 34, n. 3, pp. 671-680, Jul./Sep. 2017.

[17] GÜNDÜZ, G.; AȘIK, N., "Production and Characterization of Bacterial Cellulose with Different

Nutrient Source and Surface - Volume Ratios", Drvna industrija, v. 69, n. 2, pp. 141-148, 2018.

[18] KIZILTAS, E.E., KIZILTAS, A., GARDNER, D.J., "Synthesis of bacterial cellulose using hot water extracted wood sugars", Carbohydrate Polymers, v. 124, p. 131-138, Jun. 2015

[19] CHANDRASEKARAN, P.T., BARI, N.K., SINHA, S., "Enhanced bacterial cellulose production from Gluconobacter xylinus using super optimal broth", Cellulose, v. 24, n. 10, pp. 4367-4381, Jul. 2017.

[20] MICHALSKI, E. Z.; MENEGOL, D.; REIS, L. et al., "Efeito da suplementação de Prodex na produção de celulases e xilanases por Penicillium echinulatum em cultivos em estado sólido". XVI Encontro de Jovens Pesquisadores, Universidade de Caxias do Sul: setembro, 2008.

[21] MIRZA, M.A.; MUSHTAQ, T. "Effect of supplementing different levels of corn steep liquor on the postweaning performance of pak-karakul lambs". Pakistan Vet. Journal, 26: 135 - 137, 2006.

[22] THE CORN REFINERS ASSOCIATION. "Assessment plan off corn steep liquor in accordance with the USEPA high production volume chemical challenge program". Washington, 2006.

[23] COSTA, A.F.S., ALMEIDA, F.C.G., VINHAS, G.M., et al., "Production of bacterial cellulose by Gluconacetobacter hansenii using corn steep liquor as nutrient sources", Frontiers in Microbiology, v. 8, pp. 112, Oct. 2017.

[24] BAE, S.O., SHODA, M., "Production of bacterial cellulose by Acetobacter xylinum BPR2001 using molasses medium in a jar fermentor", Applied Microbiology and Biotechnology, v, 67, n. 1, pp. 45-51, Apr. 2005.

[25] FURLAN, S.A., SCHNEIDER, A.L.S., MERKLE, R., et al., "Formulation of a lactose-free, low-cost culture medium for the production of $\beta$-D-galactosidase by Kluyveromyces marxianus", Biotechnology Letters, v. 22, n. 7 , pp. 589-593, Apr. 2000. 
[26] KAWAGUTI, H.Y., MANRICH, E., FLEURI, L.F., et al., "Production of glucosyltransferase by Erwinia sp. using experimental design and response surface methodology", Brazilian Journal of Microbiology, v. 36, n. 3, pp. 227-234, Jul./Sep. 2005.

[27] HUTCHENS, S.A., LEÓN, R.V., O’NEILL, H.M., et al., "Statistical analysis of optimal culture conditions for Gluconacetobacter hansenii cellulose production”, Letters in Applied Microbiology, v. 44, pp. 175-180, Nov. 2006.

[28] SANTOS, S.M., CARBAJO, J.M., VILLAR, J.C., "The effect of carbon and nitrogen sources on bacterial cellulose production and properties from Gluconacetobacter sucrofermentans CECT 7291 focused on its use in degraded paper restoration", BioResources., v. 8, n. 3, pp. 3630-3645, 2013.

[29] MIKKELSEN, D., FLANAGAN, B.M., DYKES, G.A., et al., "Influence of different carbon sources on bacterial cellulose production by Gluconacetobacter xylinus strain ATCC 53524", Journal of Applied Microbiology, v. 107, n. 2, pp. 576-583, Jul. 2009.

[30] TSOUKO, E., MANDALA, I., PALOUKIS, F., et al., "Bacterial Cellulose Production from Industrial Waste and by-Product Streams”, International Journal of Molecular Sciences, v. 16, n. 7, pp. 14832-14849, Jul. 2015.

[31] ZHONG, C., ZHANG, G.-C., JIA, S.-R., et al., "Metabolic flux analysis of Gluconacetobacter xylinus for bacterial cellulose production”, Applied Microbiology and Biotechnology, v. 97, n. 14, pp. 6189-6199, Jul. 2013.

[32] TIBONI, M., MONITORAMENTO DA ATIVIDADE DE ENZIMAS DO COMPLEXO CELULOLÍTICO UTILIZANDO CELULOSE BACTERIANA COVALENTEMENTE TINGIDA COM AZUL BRILHANTE DE REMAZOL R, Dissertation of M.Sc., UFPR, Curitiba, PR, Brazil, 2011.

[33] MOHAMMADKAZEMI, F., AZIN, M., ASHORI, A., "Production of bacterial cellulose using different carbon sources and culture media", Carbohydrate Polymers, v. 117, pp. 518-523, Mar. 2015.

[34] GEA, S., REYNOLDS, C.T., ROOHPOUR, N., et al., "Investigation into the structural, morphological, mechanical and thermal behaviour of bacterial cellulose after a two-step purification process", Bioresource Technology, v. 102, n. 19, pp. 9105-9110, Oct. 2011.

[35] VAZQUEZ, A., FORESTI, M.L., CERRUTTI, P., et al., "Bacterial Cellulose from Simple and Low Cost Production Media by Gluconacetobacter xylinus", Journal of Polymers and the Environment, v. 21, n. 2, pp. 545554, Jun. 2013.

[36] BRANDES, R., CARMINATTI, C.A., OLIVEIRA, E.M., et al., "Influence of the Processing Parameters on the Characteristics of Spherical Bacterial Cellulose", Fibers and Polymers, v. 19, n. 2, pp. 297-306, Feb. 2018.

[37] RAMBO, C.R., RECOUVREUX, D.O.S., ANTÔNIO, R.V., et al., "Template assisted synthesis of porous nanofibrous cellulose membranes for tissue engineering", Materials Science and Engineering: $C$, v. 28, n. 4, pp. 549-554, May. 2008.

[38] YAN, H., CHEN, X., SONG, H., et al., "Synthesis of bacterial cellulose and bacterial cellulose nanocrystals for their applications in the stabilization of olive oil pickering emulsion", Food Hydrocolloids, v. 72, pp. 127-135, Nov. 2017.

[39] KLEMM, D., SCHUMANN, D., KRAMER, F., et al., "Nanocelluloses as innovative polymers in research and application", Advances in Polymer Science, v. 205, pp. 49-96. Ago. 2006.

[40] VIEIRA, D.C.M., SENNA, B.T.G., ISHII, M., et al., "Bacterial cellulose production by Acetobacter xylinum and Saccharomyces cerevisiae in green tea leaves and fruits juice médium", Asian Journal of Pharmaceutical and Health Sciences, v. 3, n. 2, pp. 690-698, Apr./Jun. 2013.

[41] JOZALA, A.F., PÉRTILE, R.A.N., DOS SANTOS, C.A., et al., "Bacterial cellulose production by Gluconacetobacter xylinus by employing alternative culture media”, Applied Microbiology and Biotechnology, v. 99, n. 3, pp. 1181-1190, Feb. 2015.

\section{ORCID}

Biassander Camila Tureck

Haira Gabriela Hackbarth

Eduarda Zeni Neves

Michele Cristina Formolo Garcia

Giannini Pasiznick Apati

Derce de Oliveira Souza Recouvreux

Ana Paula Testa Pezzin

Andrea Lima dos Santos Schneider https://orcid.org/0000-0003-4836-3153

https://orcid.org/0000-0001-8995-4107

https://orcid.org/0000-0001-9913-791X

https://orcid.org/0000-0002-6899-1264

https://orcid.org/0000-0003-4893-6193

https://orcid.org/0000-0001-5185-5648

https://orcid.org/0000-0001-9343-3929

https://orcid.org/0000-0002-2043-0177 